\title{
Relation Between Normal Blood Pressure and Half Fried Eggs Lovers
}

\author{
Muhammad Imran Qadir and Hafiz Kaleem Ullah* \\ Institute of Molecular Biology and Biotechnology, Pakistan \\ *Corresponding author: Hafiz Kaleem Ullah, Institute of Molecular Biology and Biotechnology, Pakistan
}

\begin{abstract}
ARTICLE INFO
Received: 慧 February 01, 2019

Published: 幽 February 13, 2019

Citation: Muhammad Imran Qadir, Hafiz Kaleem Ullah. Relation Between Normal Blood Pressure and Half Fried Eggs Lovers. Biomed J Sci \& Tech Res

\section{ABSTRACT}

Idea of the existing study was to correlate the relation between normal blood pressure and half fried eggs likeliness. . Blood line atmospheric imperativeness is also vital because it delivers white stock cells and antibodies for granting immunity and hormones. Blood pressure readings consist of two numbers first is systolic and the second is diastolic blood pressure. The systolic pressure is the higher pressure caused by the hearts muscle contraction, while the diastolic identification number is the lower pressure in the arteries. The device used to measure blood pressure is a sphygmomanometer and is measured in millimeters of atomic number $80 \mathrm{mmHg}$.
\end{abstract} 14(3)-2019. BJSTR. MS.ID.002567.
Keywords: Blood Pressure; Half Fried Eggs Likeliness; Bahauddin Zakariya University Multan; Pakistan

\section{Introduction}

Rake air atmospheric insistency is the force that movement parentage through our circulatory system. Blood line atmospheric imperativeness is also vital because it delivers white stock cells and antibodies for granting immunity and hormones. Blood pressure is synchronized by baroreceptors which spot by way of the smartness to control nervous and endocrine systems. Blood pressure that is too low is called hypotension, and pressure that is constantly is high is hypertension. Blood pressure readings consist of two numbers first is systolic and the second is diastolic blood pressure. The systolic pressure is the higher pressure caused by the hearts muscle contraction, while the diastolic identification number is the lower pressure in the arteries during the brief resting menses between heartbeats. The device used to measure blood pressure is a sphygmomanometer and is measured in millimeters of atomic number $80 \mathrm{mmHg}$, it consist of a rubber armband the manacle that is inflated by hired man or machine pump. Half fried ballock are very tasty cocked dish. These are amazing or wonderful protein in factory. Most of the people eat this cocked dish in breakfast or tiffin. Half fried testicles are tastier than omelet. These eggs are cocking in petroleum or vegetable ghee. Children's are very fond to eat it. Idea of the existing study was to correlate the relation between normal blood pressure and half fried eggs lovers [1-10].

\section{Data and Technique}

200 objects were involved in this research or project. We were used sphygmomanometer for measuring normal blood pressure. All these objects or students were my classmate.

Estimate Style: We arranged a feedback form on the subject of the relation between normal blood pressure and half fried eggs lovers.

\section{Analysis of Statistics}

a. Processing of Examining Data: M State was performed by using Statistical analysis.

\section{Calculation and Debate}

200 objects were involved in this research or project. We were used sphygmomanometer for measuring normal blood pressure. All these objects or students were my classmate. We were used Ms excel for taking the result. After knowing the blood pressure of every men and women in class room we layout these result on the 
page. Then we were found the value of lovers or hated half fried eggs and discussed in Table 1.

Table 1: Relation between normal blood pressure and half fried eggs lovers (Means $\pm S D$ ).

\begin{tabular}{|c|c|c|c|}
\hline Blood Pressure & Half Fried Eggs Fan & $\begin{array}{c}\text { Half Fried Eggs } \\
\text { Unloved }\end{array}$ & P-Value \\
\hline Systolic & $121.01 \pm 14.92$ & $118.27 \pm 13.60$ & 0.17 \\
\hline Diastolic & $74.22 \pm 11.19$ & $73.76 \pm 11.69$ & 0.77 \\
\hline $\begin{array}{c}\text { Differentiation } \\
\text { Between } \\
\text { Systolic and } \\
\text { Diastolic }\end{array}$ & $46.79 \pm 12.26$ & $44.51 \pm 13.75$ & 0.30 \\
\hline
\end{tabular}

\section{Conclusion}

We were concluded that numbers of half fried eggs lovers greater as compare to the hated half fried eggs.

\section{References}

1. Qadir MI, Malik SA (2010) Comparison of alterations in red blood cell count and alterations in hemoglobin concentration in patients suffering from rectal carcinoma undergoing 5 -fluorouracil and folic acid therapy. Pharmacology online Nl 3: 240-243.

\section{ISSN: 2574-1241}

DOI: 10.26717.BJSTR.2019.14.002567

Hafiz Kaleem Ullah. Biomed J Sci \& Tech Res

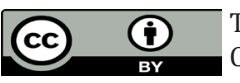

This work is licensed under Creative Commons Attribution 4.0 License

Submission Link: https://biomedres.us/submit-manuscript.php
2. Qadir MI, Noor A (2018) Anemias. Rare \& Uncommon Diseases. Cambridge Scholars Publishing. Newcastle, England. ISBN: 978-1-52751807-0.

3. Qadir MI, Javid A (2018) Awareness about Crohn's Disease in biotechnology students. Glo Adv Res J Med Medical Sci 7(3): 062-064.

4. Qadir MI, Saleem A (2018) Awareness about ischemic heart disease in university biotechnology students. Glo Adv Res J Med Medical Sci 7(3): 059-061.

5. Qadir MI, Ishfaq S (2018) Awareness about hypertension in biology students. Int J Mod Pharma Res 7(2): 08-10.

6. Qadir MI, Mehwish (2018) Awareness about psoriasis disease. Int J Mod Pharma Res 7(2): 17-18.

7. Qadir MI, Shahzad R (2018) Awareness about obesity in postgraduate students of biotechnology. Int J Mod Pharma Res, 7(2): 14-16.

8. Qadir MI, Rizvi M (2018) Awareness about thalassemia in post graduate students. MOJ Lymphology \& Phlebology 2(1): 14-16.

9. Qadir MI, Ghalia BA (2018) Awareness survey about colorectal cancer in students of M. Phil Biotechnology at Bahauddin Zakariya University, Multan, Pakistan. Nov Appro in Can Study 1(3).

10. Qadir MI, Saba G (2018) Awareness about intestinal cancer in university student. Nov Appro in Can Study 1(3).

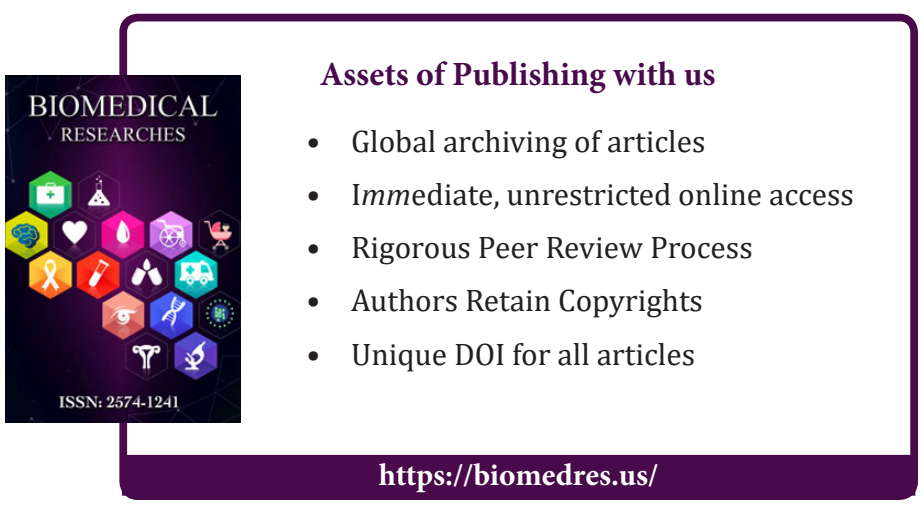

